\title{
Efektivitas Sidang Keliling Pengadilan Agama Sampit Dalam Penyelesaian Perkara Hukum Keluarga
}

\author{
M. Zaki Hidayatullah \\ STAFF di KUA Sampit \\ zakihidayatullah76@gmail.com
}

\begin{abstract}
Research conducted by the researchers focused on three things. First, how the background of the idea of the circuit court of the Religious Courts Sampit. Second, what is the basic provisions that allow a circuit court Sampit Religious Court. Third, how the effectiveness of the implementation of the circuit court Sampit Religious Court. This research is the study of law (legal research) is research that uses the type of sociology of law studies with persefektif EMIC. Using descriptive qualitative approach and a sociological approach to examine perceptions and behaviors that occur in the field of law. These results indicate that the legal basis that allows the circuit court Sampit Religious Court that the Supreme Court Circular (SEMA) No. 10 Year 2010 on Guidelines for Providing Legal Aid, gave an order from the High Court of Religion and Government Contracting Palangkaraya East Kotawaringin with DIPA funds given to the implementation of circuit courts Operational costs. While the effectiveness of the implementation circuit court conducted Religious Courts Sampit runs well and is very effective for society.
\end{abstract}

Keywoards: Effectiveness, tour court settlement and sampit.

\section{A. Pendahuluan}

Peradilan merupakan lembaga pemerintahan yang menangani dalam bidang hukum. Salah satu tugas dari lembaga ini adalah menegakkan hukum secara adil dan benar. Sebagaimana yang telah diterangkan oleh Allah SWT dalam firmannya sebagai berikut :

Terjemahan: "Mereka itu adalah orang-orang yang suka mendengar berita bohong, banyak memakan yang haram. jika mereka (orang Yahudi) datang kepadamu (untuk meminta putusan), Maka putuskanlah (perkara itu) diantara mereka, atau berpalinglah dari mereka; jika kamu berpaling dari mereka Maka mereka tidak akan memberi mudharat kepadamu sedikitpun. dan jika kamu memutuskan perkara mereka, Maka putuskanlah (perkara itu) diantara mereka dengan adil, Sesungguhnya Allah menyukai orang-orang yang adil”. ${ }^{1}$

${ }^{1}$ Departemen Agama Republik Indonesia, Al-Qur'an dan Terjemahan (QS Al-Maidah : 42, Depok: Mushaf Ar-Rusydi, 2008, hal. 115. 
Kata-kata peradilan sama artinya dengan istilah dalam Fiqh yang berbunyi "qadha" dan "aqdliyah". 2 Ali Duraib memberikan 6 (enam) arti untuk kata al-qadha dengan makna yang berbeda-beda yaitu: Al-Hukmu, yang bermakna hukum atau putusan (QS. An-nisa':65). Al-Khatim wa AlLuzuиm, yang bermakna mengambil putusan dan mengharuskan (QS. Saba': 14). Al-Amr, yang berarti perintah (QS. Al-Isra': 23). Al-Bayan, berarti penjelas (QS. Thaha : 114). Al-Faraagh Min As-Sai' wa Al-Intiba' Min Hu, yang berarti selesai dari melaksanakan sesuatu (QS. Yusuf: 41). Al-Amal berarti amal atau tindakan (QS. Al-Qashash: 15$){ }^{3}$

Pengertian pengadilan secara khusus, yaitu suatu lembaga tempat mengadili atau menyelesaikan sengketa hukum dalam rangka kekuasaan kehakiman yang mempunyai kekuasaan absolute dan relative sesuai peraturan perundang-undangan. Dalam bahasa Arab disebut al-Mahkamah. ${ }^{4}$ Lingkungan peradilan umum terdiri dari Pengadilan Negeri sebagai pengadilan tingkat pertama dan Pengadilan Tinggi sebagai pengadilan tingkat banding dan berpuncak di Mahkamah Agung Republik Indonesia. Lingkungan peradilan agama terdiri dari Pengadilan Agama sebagai pengadilan agama tingkat pertama dan Pengadilan Tinggi Agama sebagai pengadilan tingkat banding dan berpuncak di Mahkamah Agung Republik Indonesia (MA-RI). ${ }^{5}$

Lingkungan peradilan militer terdiri dari Mahkamah Militer sebagai pengadilan tingkat pertama dan Mahkamah Militer Tinggi sebagai pengadilan tingkat banding dan berpuncak di MA-RI. Sedangkan untuk pengadilan tata usaha negara terdiri dari Pengadilan Tata Usaha Negara sebagai pengadilan tingkat pertama dan Pengadilan Tinggi Tata Usaha Negara sebagai

${ }^{2}$ Zaini Ahmad Noeh dan Abdul Basit Adnan, Sejarah Singkat Pengadilan Agama Islam di Indonesia, Surabaya: PT Bina Ilmu, 1980, hal. 15.

${ }^{3}$ Abdul Halim, Peradilan Agama dalam Politik Hukum di Indonesia, Jakarta: Raja Grafindo Persada, 2000, hal. 28-29.

${ }^{4}$ Sulaikhan Lubis, Hukum Acara Perdata Peradilan Agama di Indonesia, Jakarta: Prenada Media, 2005, hal. 3.

${ }^{5}$ Ahmad Mujahidin, Pembaharuan Hukum Acara Perdata Peradilan Agama dan Mahkamah Syar'iyyah di Indonesia, Jakarta: IKAHI, 2008, hal. 3-4. 
pengadilan tingkat banding dan berpuncak pula di MA-RI. ${ }^{6}$

Guna memenuhi kebutuhan masyarakat muslim akan penegakkan keadilan, pemerintah mewujudkan dan menegaskan kedudukan Peradilan Agama sebagai salah satu badan kekuasaan kehakiman di Indonesia. ${ }^{7}$ Untuk Peradilan Agama sendiri merupakan terjemahan dari bahas Belanda, Godstientige Rechtspaak. Godstientige berarti ibadah atau agama. Dan Rechtspaak berarti peradilan, yaitu upaya untuk mencari keadilan atau penyelesaian hukum yang dilakukan menurut peraturan-peraturan dan dalam lembaga-lembaga tertentu dalam pengadilan. ${ }^{8}$

Lembaga Peradilan Agama di Indonesia terkonsepsi dan diakui dalam Undang-Undang No. 14 Tahun 1970 tentang Undang-Undang Kekuasaan Kehakiman yang menyebutkan bahwa, kekuasaan kehakiman dilakukan oleh Pengadilan dalam lingkungan; Peradilan umum, Peradilan Agama, Peradilan Militer dan Peradilan Tata Usaha Negara. Begitu pula Undang-undang No. 7 Tahun 1989 tentang Peradilan Agama. ${ }^{9}$

Mengenai kewenangan absolute Peradilan Agama telah dirumuskan dalam pasal 49 Undang-undang Nomor 50 Tahun 2009 amandemen dari Undang-undang Nomor 3 tahun 2006 tentang Peradilan Agama yaitu menyelesaikan perkara-perkara di tingkat pertama antara orang-orang yang beragama Islam di bidang: perkawinan, kewarisan, wasiat, hibah, wakaf, zakat, infaq, sedekah dan ekonomi syari'ah. ${ }^{10}$ Dalam pelaksanaannya hukum acara berlaku bagi setiap peradilan. Begitu pula halnya untuk Peradilan Agama berlaku hukum acara perdata Peradilan Agama. Hukum acara

${ }^{6}$ Ibid., hal. 4.

${ }^{7}$ Sulaikhan Lubis, Hukum Acara Perdata Peradilan Agama di Indonesia, Jakarta: RajaGrafindo Persada, 2000, hal. 1.

${ }^{8}$ Zaini Ahmad Noeh dan Abdul Basit Adnan, Sejarah Singkat Pengadilan Agama Islam di Indonesia, Surabaya: PT Bina Ilmu, 1980, hal. 15.

${ }^{9}$ Ibid., hal. 12.

${ }^{10}$ Chatib Rasyid dan Syaifuddin, Hukum Acara Perdata dalam Teori dan Praktik pada Peradilan Agama, Yogyakarta: UII Perss, 2009, hal. 13. 
Pengadilan Agama adalah cara bagaimana bertindak di muka Pengadilan Agama dan bagaimana cara hakim agar hukum itu berjalan sebagaimana mestinya. Dalam prakteknya proses persidangan itu melalui beberapa tahapan. Dalam hukum acara perdata, jika proses persidangan berjalan lancar maka jumlah tahap persidangan lebih kurang dari 8 (delapan) kali, yang terdiri dari sidang pertama sampai dengan putusan hakim. ${ }^{11}$

Dalam Surat Edaran Mahkamah Agung Pasal 1 ayat 8 ditentukan sidang keliling adalah sidang yang dilaksanakan secara tetap (berkala) atau sewaktu-waktu oleh pengadilan di suatu tempat yang ada dalam wilayah hukumnya tetapi di luar tempat kedudukan pengadilan. ${ }^{12}$

Sidang keliling sangat membantu masyarakat dalam memperjuangkan keadilan yang hakiki, disaat masyarakat membutuhkan penegak hukum untuk menyelesaikan perkara yang membutuhkan putusan untuk memperkuat kekuatan hukumnya, akan tetapi terhalang oleh hambatan-hambatan yang mungkin tidak mampu dijangkau oleh mereka, maka disaat itulah proses sidang keliling sangat membantu dan dibutuhkan. Berikut adalah manfaat yang didapat dengan adanya proses sidang keliling: Lokasi sidang lebih dekat dengan tempat tinggal yang mengajukan perkara. Biaya transportasi lebih ringan. Lebih menghemat waktu. ${ }^{13}$

Pengadilan Agama Sampit terletak di Sampit yang merupakan Ibukota Kabupaten Kotawaringin Timur, Provensi Kalimantan Tengah. Kabupaten Kotawaringin Timur memiliki luas wilayah kurang lebih $16.796 \mathrm{~km}^{2}$ dan berpenduduk sebanyak 429.931 Jiwa. Kabupaten ini terdiri dari 17

${ }^{11}$ R. Soeroso, Praktik Hukum Acara Perdata: Tata Cara dan Proses Persidangan, Jakarta: Sinar Grafika, Cet. V, 2003, hal. 44.

${ }^{12}$ Surat Edaran Mahkamah Agung Nomor 10 Tahun 2010 Tentang Pedoman Pemberian bantuan hukum pasal 1 ayat (8) ditentukan sidang keliling, Http://bawas.mahkamahagung.go.id /bawasdoc/doc/sema.no_10 tahun_2010.pdf. Diunduh pada tanggal 7 Mei 2015 pukul 16:00 WIB.

${ }^{13}$ Tehapan-tahapan persidangan dalam persidangan keliling, Http://www.pajakartautara.go.id/website/edukasi-masyarakat/proses-tahapan-persidangan.html. Diunduh pada tanggal 7 Mei 2015 pukul 16:00 WIB. 
Kecamatan, 168 Kelurahan/Desa. Yurisdiksi Pengadilan Agama Sampit mempunyai 3 (tiga) Wilayah Hukum, yaitu Kabupaten Kotawaringin Timur, Kabupaten Katingan, dan Kabupaten Seruyan. ${ }^{14}$

Mengingat aktifitas dan ruang lingkup praktek peradilan agama terkait hukum acara sidang keliling tersebut tidak diatur secara khusus dalam Surat Edaran Mahkamah Agung, peneliti telah melakukan wawancara dengan hakim Pengadilan Agama Sampit dan memperoleh penjelasan tentang bagaimana pelaksanaan sidang keliling Pengadilan Agama Sampit. Sidang keliling ini terjadi karena telah mendapat perintah langsung dari Pusat dan Pengadilan Agama Tinggi Palangka Raya serta karena adanya dana DIPA yang telah dianggarkan oleh Pemerintah Kabupaten Kotawaringin Timur. Selain itu karena wilayah pemekaran masih belum memiliki Pengadilan Agama dan jarak lumayan jauh yang ditempuh untuk sampai Kepengadilan Agama Sampit. Laporan banyaknya permintaan masyarakat dalam kasus perceraian di wilayah pemekaran juga menjadi pertimbangan para pihak Pengadilan Agama Sampit untuk melaksanakan sidang keliling ini. Dalam hal ini peneliti ingin melakukan kajian mendalam tentang "EFEKTIVITAS SIDANG KELILING PENGADILAN AGAMA SAMPIT DALAM PENYELESAIAN PERKARA HUKUM KELUARGA".

\section{B. Kajian Pustaka}

Berdasarkan penelusuran yang penulis lakukan, terdapat beberapa peneliti yang telah melakukan penelitian tentang sidang keliling, namun yang dicantumkan dalam penelitian terdahulu ini hanya 2 (dua) penelitian yang menurut penulis berkaitan dengan judul yang penulis angkat, diantaranya:

Skripsi yang ditulis oleh Indah Umaroh yang berjudul "Analisis Sidang Keliling Perkara Cerai Gugat Di Wilayah Hukum Pengadilan Agama Mojokerto menurut Surat Edaran Mahkamah Agung (Sema) No.10 Tahun

${ }^{14}$ Tata letak dan daerah yuridiksi Pengadilan Agama Sampit, Http://www.pa-sampit.go.id/. Diunduh pada tanggal 13 Mei 2015. pukul 19:21 WIB. 
2010". ${ }^{15}$ Rumusan masalah dalam penelitian ini diantaranya pertama, bagaimana landasan Pengadilan Agama Mojokerto melakukan sidang keliling. Kedua, bagaimana proses sidang keliling yang dilakukan di Pengadilan Agama Mojokerto dalam perkara cerai gugat serta implikasinya terhadap meningkatnya angka perceraian di Mojokerto. Berdasarkan hasil penelitian tersebut dapat diketahui:

Pertama, bahwa yang melandasi sidang keliling Pengadilan Agama Mojokerto melakukan sidang keliling ialah Surat Edaran Makamah Agung (Sema) No. 10 Tahun 2010. Kedua, pelaksanaan dan proses sidang keliling yang dilakukan Pengadilan Agama Mojokerto mengikuti hukum acara peradilan yang berlaku. Baik proses pengajuan, pemanggilan maupun sidangnya, dengan ketentuan tersebut sidang berjalan secara efektif dan efisien dan dalam penelitian ini penulis menemukan adanya peningkatan angka cerai gugat yang dilakukan masyarakat Mojokerto, dengan adanya sidang keliling yang dilakukan Pengadilan agama Mojokerto yang bertempat dikantor PKK kecamatan Trawas Kabupaten Mojokerto. Sidang keliling dilakukan dua kali, pada tanggal 27 April dan 9 Mei 2011 dengan 12 perkara.

Selanjutnya Tesis yang ditulis oleh Fariha yang berjudul "Efektifitas Penyelesaian Perkara Perceraian Melalui Sistem Sidang Keliling di Pengadilan Agama Kabupaten Malang Jawa Timur". ${ }^{16}$ Rumusan masalah dalam penelitian ini ada 2 (dua) diantaranya: Pertama, bagaimanakah efektifitas pelaksanaan sidang keliling Pengadilan Agama di Kabupaten Malang. Kedua, Apa sajakah faktor pendorong dan penghambat dalam pelaksanaan sidang keliling Pengadilan Agama di Kabupaten Malang. Berdasarkan hasil penelitian tersebut dapat diketahui:

\footnotetext{
${ }^{15}$ Indah Umaroh, ANALISIS SIDANG KELILING PERKARA CERAI GUGAT DI WILAYAH HUKUM PENGADILAN AGAMA MOJOKERTO MENURUT SURAT EDARAN MAHKAMAH AGUNG (SEMA) NOMOR 10 TAHUN 2010, Http://digilib.sunanampel.ac.id/gdl.php?mod=browse\&op=read\&id=jiptiai--indahumaro-9504. Diunduh pada tanggal 25 April 2015, pukul 20:53 WIB. (dalam bentuk PDF).

${ }^{16}$ Fariha, EFEKTIVITAS PENYELESAIAN PERKARA PERCERAIAN MELALUI SISTEM SIDANG KELILING DI PENGADILAN AGAMA KABUPATEN MALANG JAWA TIMUR, Http://lib.uin-malang.ac.id/?mod=th_detail\&id=10780008. Diunduh pada tanggal 28 April 2015, pukul 15:49 WIB. (dalam bentuk PDF).
} 
Pertama, efektifitas penyelesaian perkara perceraian melalui sistem sidang keliling di Pengadilan Agama Kabupaten Malang meliputi waktu dan biaya transportasi saja, adapun mengenai teknis pelaksanaan dan panjar biaya perkara tetap sama seperti halnya persidangan pada umumnya, penyelesaian perkara perceraian melalui sistem sidang keliling sendiri belum bisa mengurangi angka perceraian di Pengadilan Agama Kabupaten Malang hanya saja dapat mempercepat penyelesaian perkara perceraian. Kedua, faktor yang mendukung di antaranya tersedianya infrastruktur, sarana dan prasarana, lokasi lebih dekat, dan proses cepat. Adapun tidak ditemukan faktor penghambat dalam pelaksanaan sidang keliling ini.

Dari deskripsi di atas sangat jelas bahwa masalah yang penulis bahas mengenai "Efektivitas Sidang Keliling Pengadilan Agama Sampit dalam Penyelesaian Perkara Hukum Keluarga” berbeda dengan peneliti sebelumnya. Selain waktu dan tempat penelitian yang berbeda. Dalam skripsi ini lebih menekankan pada bagaimana implementasi hukum acara pada pelaksaan sidang keliling, sudah efektifkah yang di laksanakan dan apa saja kendala dalam pelaksanaan sidang keliling Pengadilan Agama Sampit.

\section{Tabel 1}

\section{Persamaan dan Perbedaan Serta Kedudukan Penelitian Penulis}

\begin{tabular}{|c|c|c|c|}
\hline No & $\begin{array}{l}\text { Nama, Judul, Tahun, dan } \\
\text { Pendekatan Penelitian }\end{array}$ & Persamaan & $\begin{array}{c}\text { Perbedaan dan } \\
\text { Kedudukan Penulis }\end{array}$ \\
\hline 1. & $\begin{array}{l}\text { Indah Umaroh yang berjudul } \\
\text { "Analisis Sidang Keliling } \\
\text { Perkara Cerai Gugat Di } \\
\text { Wilayah Hukum Pengadilan } \\
\text { Agama Mojokerto menurut } \\
\text { Surat Edaran Mahkamah } \\
\text { Agung (Sema) No.10 Tahun } \\
\text { 2010" }\end{array}$ & Sidang Keliling & $\begin{array}{l}\text { 1. Bagaimana latar } \\
\text { belakang ide sidang } \\
\text { keliling pada } \\
\text { Pengadilan Agama } \\
\text { Sampit } \\
\text { 2. Apa dasar ketentuan } \\
\text { yang membolehkan } \\
\text { sidang keliling pada }\end{array}$ \\
\hline 2 & $\begin{array}{l}\text { Fariha yang berjudul } \\
\text { "Efektifitas Penyelesaian } \\
\text { Perkara Perceraian Melalui } \\
\text { Sistem Sidang Keliling di } \\
\text { Pengadilan Agama Kabupaten } \\
\text { Malang Jawa Timur" }\end{array}$ & Sidang Keliling & $\begin{array}{l}\text { 3. Bagaimana efektivitas } \\
\text { pelaksanaan sidang } \\
\text { keliling Pengadilan } \\
\text { Agama Sampit }\end{array}$ \\
\hline
\end{tabular}


Guna memenuhi kebutuhan masyarakat muslim akan penegakkan keadilan, pemerintah mewujudkan dan menegaskan kedudukan Peradilan Agama sebagai salah satu badan kekuasaan kehakiman di Indonesia. ${ }^{17}$ Untuk Peradilan Agama sendiri merupakan terjemahan dari bahas Belanda, Godstientige Rechtspaak. Godstientige berarti ibadah atau agama. Dan Rechtspaak berarti peradilan, yaitu upaya untuk mencari keadilan atau penyelesaian hukum yang dilakukan menurut peraturan-peraturan dan dalam lembaga-lembaga tertentu dalam pengadilan. ${ }^{18}$

Lembaga Peradilan Agama di Indonesia terkonsepsi dan diakui dalam Undang-Undang No. 14 Tahun 1970 tentang Undang-Undang Kekuasaan Kehakiman yang menyebutkan bahwa, kekuasaan kehakiman dilakukan oleh Pengadilan dalam lingkungan Peradilan umum, Peradilan Agama, Peradilan Militer dan Peradilan Tata Usaha Negara. Begitu pula Undang-undang No. 7 Tahun 1989 tentang Peradilan Agama. ${ }^{19}$ Mengenai kewenangan absolute Peradilan Agama telah dirumuskan dalam pasal 49 Undang-undang Nomor 50 Tahun 2009 amandemen dari Undang-undang Nomor 3 tahun 2006 tentang Peradilan Agama yaitu menyelesaikan perkara-perkara di tingkat pertama antara orang-orang yang beragama Islam di bidang perkawinan, kewarisan, wasiat, hibah, wakaf, zakat, infaq, sedekah dan ekonomi syari'ah. $^{20}$

Dalam pelaksanaannya hukum acara berlaku bagi setiap peradilan. Begitu pula halnya untuk Peradilan Agama berlaku hukum acara perdata Peradilan Agama. Hukum acara Pengadilan Agama adalah cara bagaimana bertindak di muka Pengadilan Agama dan bagaimana cara hakim agar hukum itu berjalan sebagaimana mestinya. Dalam prakteknya proses persidangan itu melalui beberapa tahapan. Dalam hukum acara perdata, jika proses

\footnotetext{
${ }^{17}$ Sulaikhan Lubis, Hukum Acara Perdata Peradilan Agama di Indonesia..., hal. 1.

${ }^{18}$ Zaini Ahmad Noeh dan Abdul Basit Adnan, Sejarah Singkat Pengadilan Agama Islam di Indonesia....., hal. 15.

${ }^{19}$ Ibid., hal. 12.

${ }^{20}$ Chatib Rasyid, dan Syaifuddin, Hukum Acara Perdata dalam Teori dan Praktik pada Peradilan Agama...., hal. 13.
} 
persidangan berjalan lancar maka jumlah tahap persidangan lebih kurang dari 8 (delapan) kali, yang terdiri dari sidang pertama sampai dengan putusan hakim..$^{21}$

\section{Metode Penelitian}

Penelitian hukum (legal research) ini adalah menggunakan tipe kajian sosiologi hukum dengan persefektif emik. Kajian hukum secara sosiologis sebagaimana juga hukum sebagai fakta hukum, maka yang dominan digunakan ialah penelitian kualitatif (yang bersifat subyektif dan interpretif). ${ }^{22}$ Dalam hal ini peneliti telah melakukan penelitian tentang efektivitas sidang keliling Pengadilan Agama Sampit Dalam Penyelesaian Perkara Hukum Keluarga. Penelitian ini merupakan penelitian yang menggunakan pendekatan kualitatif deskriptif. Menurut Soerjono Soekanto, pendekatan kualitatif sebenarnya merupakan tata cara penelitian yang menghasilkan data deskriptif, yaitu apa yang dinyatakan oleh responden secara lisan atau tertulis dan

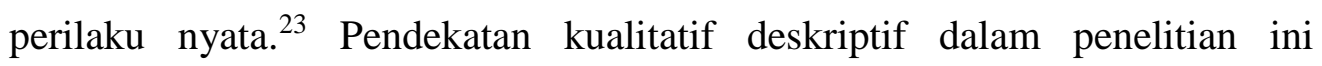
dimaksudkan untuk mengetahui dan menggambarkan efektivitas sidang keliling Pengadilan Agama Sampit, khususnya berkenaan dengan Surat Edaran Mahkamah Agung mengenai pedoman pemberian bantuan hukum sebagaimana yang telah ditentukan SEMA Nomor 10 Tahun 2010 mengenai

\footnotetext{
${ }^{21}$ R. Soeroso, Praktik Hukum Acara Perdata: Tata Cara dan Proses Persidangan...., hal. 44.

${ }^{22}$ Sabian Utsman, Metodologi Penelitian Hukum Progresif, Yogyakarta: Pustaka Pelajar, 2014, hal. 98. Lihat juga Sabian Utsman, Dasar-dasar Sosiologi Hukum, Yogyakarta: Pustaka Pelajar, 2009, hal. 310. Lihat juga Sabian Utsman, Restorative Justice (Hukum Masyarakat Nelayan Saka dalam Sistem Hukum Nasional) Hukum Penguasaan, Pemilikan dan Konflik Saka Sebuah Penelitian Hukum (Legal Research), Yogyakarta: Pustaka Pelajar, 2013, hal. 66. Lihat juga Soerjono Soekanto, Pengantar Penelitian Hukum, Jakarta: Universitas Indonesia (UI-Press), 1986, hal. 11-12. Lihat juga Soerjono Soekanto dan Sri Mamudji, Penelitian Hukum Normatif Suatu Tinjauan Singkat, Jakarta: PT RajaGrafindo Persada, 2001, hal. 14. Lihat juga Supranto, Metode Penelitian Hukum dan Statistik, Jakarta: Rineka Cipta, 2003, hal. 2. Lihat juga Amirudin dan Zainal Asikin, Pengantar Metode Penelitian Hukum, Jakarta: PT RajaGrafindo Persada, 2006, hal. 30. Lihat juga Bambang Sugono, Metodologi Penelitian Hukum Suatu Pengantar, Jakarta: PT RajaGrafindo Persada, 1998, hal. 42.
}

${ }^{23}$ Soerjono Soekanto, Pengantar Penelitian Hukum, Jakarta: Universitas Indonesia (UIPress), 1986, hal. 32. 
penjelasan sidang keliling. Keabsahan data digunakan untuk menunjukkan bahwa semua data yang diperoleh dan diteliti relevan dengan yang sesungguhnya. Hal ini dilakukan untuk menjamin bahwa data yang diperoleh dan dikumpulkan tersebut benar adanya. Selanjutnya, untuk memperoleh tingkat keabsahan data yang akurat, pada penelitian ini menggunakan triangulasi. Triangulasi adalah salah satu dari banyak teknik dalam keabsahan bahan dan data hukum yang sudah terkumpul. ${ }^{24}$

Penelitian ini menggunakan triangulasi dengan sumber data yaitu membandingkan atau mengecek balik derajat kepercayaan suatu informasi melalui waktu dan alat yang berbeda dalam metode kualitatif. Teknik ini untuk menjamin kebenaran dan kepastian data tersebut. ${ }^{25}$

\section{Pembahsan}

Dalam Surat Edaran Mahkamah Agung Pasal 1 ayat 8 ditentukan sidang keliling adalah sidang yang dilaksanakan secara tetap (berkala) atau sewaktu-waktu oleh pengadilan di suatu tempat yang ada dalam wilayah hukumnya tetapi di luar tempat kedudukan pengadilan. ${ }^{26}$ Adapun arti spesifik dari sidang keliling adalah sidang pengadilan yang dilaksanakan di luar gedung pengadilan yang diperuntukkan bagi masyarakat yang mengalami hambatan untuk datang ke kantor pengadilan karena alasan jarak, transportasi dan biaya. $^{27}$ Sidang keliling sangat membantu masyarakat dalam memperjuangkan keadilan yang hakiki, disaat masyarakat membutuhkan

\footnotetext{
${ }^{24}$ Sabian Ustman, Metodologi Penelitian Hukum Progresif, Yogyakarta: Pustaka Pelajar, 2014, hal. 110 .

${ }^{25}$ Burhan Bungin, Penelitian Kualitatif: Komunikasi, Ekonomi, Kebijakan Publik, dan Ilmu Sosial Lainnya, Jakarta: Kencana, 2009, hal. 256-257.

${ }^{26}$ Surat Edaran Mahkamah Agung Nomor 10 Tahun 2010 Tentang Pedoman Pemberian bantuan hukum pasal 1 ayat (8) ditentukan sidang keliling, Http://bawas.mahkamahagung.go.id /bawasdoc/doc/sema.no_10 tahun_2010.pdf. Diunduh pada tanggal 7 Mei 2015 pukul 16:00 WIB

${ }^{27}$ Tehapan-tahapan persidangan dalam persidangan keliling, Http://www.pajakartautara.go.id/website/edukasi-masyarakat/proses-tahapan-persidangan.html. Diunduh pada tanggal 7 Mei 2015 pukul 16:00 WIB.
} 
penegak hukum untuk menyelesaikan perkara yang membutuhkan putusan untuk memperkuat kekuatan hukumnya, akan tetapi terhalang oleh hambatanhambatan yang mungkin tidak mampu di jangkau oleh mereka, maka disaat itulah proses sidang keliling sangat membantu dan dibutuhkan. Berikut adalah manfaat yang didapat dengan adanya proses sidang keliling: Lokasi sidang lebih dekat dengan tempat tinggal yang mengajukan perkara. Biaya transportasi lebih ringan. Lebih menghemat waktu. ${ }^{28}$

Untuk prosedur sidang keliling sama dengan sidang di Pengadilan Agama pada umumnya hanya yang membedakan tempat dilakukannya sidang keliling tidak di dalam ruang Pengadilan Agama akan tetapi di luar pengadilan dan waktunya untuk acara sidang keliling di Pengadilan Agama Sampit dilakukan dalam waktu singkat yaitu hanya satu hari oleh karena itu sidang keliling ini sekarang tidak lagi menggunakan istilah sidang keliling akan tetapi sidang diluar pengadilan. Penelitian hukum (legal research) ini adalah menggunakan tipe kajian sosiologi hukum dengan persefektif emik. Kajian hukum secara sosiologis sebagaimana juga hukum sebagai fakta hukum, maka yang dominan digunakan ialah penelitian kualitatif (yang bersifat subyektif dan interpretif). ${ }^{29}$ Dalam hal ini peneliti telah melakukan penelitian tentang efektivitas sidang keliling Pengadilan Agama Sampit Dalam Penyelesaian Perkara Hukum Keluarga.

Penelitian ini merupakan penelitian yang menggunakan pendekatan

${ }^{28}$ Ibid.,

${ }^{29}$ Sabian Utsman, Metodologi Penelitian Hukum Progresif, Yogyakarta: Pustaka Pelajar, 2014, hal. 98. Lihat juga Sabian Utsman, Dasar-dasar Sosiologi Hukum, Yogyakarta: Pustaka Pelajar, 2009, hal. 310. Lihat juga Sabian Utsman, Restorative Justice (Hukum Masyarakat Nelayan Saka dalam Sistem Hukum Nasional) Hukum Penguasaan, Pemilikan dan Konflik Saka Sebuah Penelitian Hukum (Legal Research), Yogyakarta: Pustaka Pelajar, 2013, hal. 66. Lihat juga Soerjono Soekanto, Pengantar Penelitian Hukum, Jakarta: Universitas Indonesia (UI-Press), 1986, hal. 11-12. Lihat juga Soerjono Soekanto dan Sri Mamudji, Penelitian Hukum Normatif Suatu Tinjauan Singkat, Jakarta: PT RajaGrafindo Persada, 2001, hal. 14. Lihat juga Supranto, Metode Penelitian Hukum dan Statistik, Jakarta: Rineka Cipta, 2003, hal. 2. Lihat juga Amirudin dan Zainal Asikin, Pengantar Metode Penelitian Hukum, Jakarta: PT RajaGrafindo Persada, 2006, hal. 30. Lihat juga Bambang Sugono, Metodologi Penelitian Hukum Suatu Pengantar, Jakarta: PT RajaGrafindo Persada, 1998, hal. 42. 
kualitatif deskriptif. Menurut Soerjono Soekanto, pendekatan kualitatif sebenarnya merupakan tata cara penelitian yang menghasilkan data deskriptif, yaitu apa yang dinyatakan oleh responden secara lisan atau tertulis dan perilaku nyata. ${ }^{30}$ Pendekatan kualitatif deskriptif dalam penelitian ini dimaksudkan untuk mengetahui dan menggambarkan efektivitas sidang keliling Pengadilan Agama Sampit, khususnya berkenaan dengan Surat Edaran Mahkamah Agung mengenai pedoman pemberian bantuan hukum sebagaimana yang telah ditentukan SEMA Nomor 10 Tahun 2010 mengenai penjelasan sidang keliling.

Menurut hakim AR, yang melatar belakangi pelaksanaan sidang keliling Pengadilan Agama Sampit ini yang pertama itu adalah jarak yang jauh seperti pihak di Kasongan Kecamatan Katingan Hilir jarak yang ditempuh untuk ke Pengadilan Agama lumayan jauh. Kedua masalah geografis juga menjadi pertimbangan para hakim dalam melatar belakangi terjadinya sidang keliling tersebut, karena medan yang dilalui tidak hanya melewati jalur darat akan tetapi ada juga yang melalui jalur perairan. ${ }^{31}$ Tidak jauh berbeda dengan penjelasan hakim AR, hakim $M$ dan hakim AG juga menyatakan bahwa yang melatar belakangi ide terjadinya sidang keliling di Pengadilan Agama Sampit ialah agar masyarakat yang jauh juga mendapatkan layanan hukum dari Pengadilan Agama Sampit karena di Kabupaten Kotawaringin Timur ini baru mengalami pemekaran dan masih banyak kabupaten-kabupaten yang mengalami pemekaran tersebut masih belum memiliki Pengadilan Agama. ${ }^{32}$ Hakim AG menekankan yang sangat berpengaruh untuk melatar belakangi terjadinya sidang keliling di Pengadilan Agama Sampit ini karena mengatur SEMA No.10 Tahun 2010 telah mengatur hal tersebut yaitu sebagai salah satu bantuan hukum yang diberikan oleh

\footnotetext{
${ }^{30}$ Soerjono Soekanto, Pengantar Penelitian Hukum, Jakarta: Universitas Indonesia (UIPress), 1986, hal. 32.

${ }^{31}$ Hasil wawancara dengan hakim AR pada tanggal 12 November 2015 pukul 09:48 WIB.

${ }^{32}$ Hasil wawancara dengan hakim M pada tanggal 19 November 2015 pukul 13:25 WIB dan AG pada tanggal 19 November 2015 pukul 14:00 WIB.
} 
pengadilan agama kepada masyarakat dan juga karena adanya dana DIPA yang diberikan oleh Pemerintah Kabupaten Kotawaringin Timur sebagai pendukung latar belakang ide pelaksanaan sidang keliling di Pengadilan Agama Sampit. ${ }^{33}$

Mengacu kepada pendapat hakim-hakim di atas, mengenai latar belakang ide sidang keliling di Pengadilan Agama Sampit, peneliti dapat memahami ada beberapa faktor yang melatar belakangi sidang keliling. Pertama, karena SEMA no. 10 tahun 2010 telah mengaturnya yaitu sebagai bantuan hukum untuk masyarakat. Kedua, karena adanya dana dari pemerintah Kabupaten Kotawaringin Timur. Ketiga, karena jarak yang ditempuh oleh masyarakat untuk mendapatkan keadilan cukup jauh. Dan yang terakhir, karena letak geografis yang ada dilewati tidak hanya melewati jalur darat akan tetapi ada juga yang melewati jalur perairan. Membicarakan tentang dasar hukum yang memperbolehkan sidang keliling Pengadilan Agama Sampit para hakim Pengadilan Agama Sampit sependapat untuk dasar kententuan yang memperbolehkan sidang keliling yaitu SEMA Nomor 10 Tahun 2010 Tentang Pedoman Pemberian Bantuan Hukum. Bantuan Hukum yang diberikan oleh Pengadilan kepada masyarakat dalam rangka justice for all sebenarnya ada 3 macam yaitu Posbakum (Pos Bantuan Hukum), Prodeo (beracara secara cuma-cuma) dan Sidang keliling. Pengadilan Agama Sampit memungkinkan untuk menggelar sidang keliling karena telah mendapat persetujuan dari Pengadilan Agama Tinggi Palangka Raya dan Mahkamah Agung Republik Indonesia. Dengan diberikannya DIPA oleh pemerintah Kabupaten Kotawaringin Timur untuk biaya operasional penyelenggaraan sidang keliling.

Terkait pelaksanaan sidang keliling yang dilaksanakan pada Pengadilan Agama Sampit pada dasarnya, pelaksanaannya menggunakan hukum acara yang sama dengan hukum acara yang berlaku pada sidang biasa di gedung Pengadilan Agama Sampit, karena secara teknis tidak ada

\footnotetext{
${ }^{33}$ Hasil wawancara dengan hakim AG pada tanggal 19 November 2015 pukul 14:00 WIB.
} 
peraturan yang menerangkan tentang tata cara pelaksanaan sidang keliling secara rinci. Dalam Surat Edaran Mahkamah Agung (SEMA) Nomor 10 Tahun 2010 Tentang Pedoman Pemberian Bantuan Hukum hanya menjelaskan secara umum tentang penyelenggaraan sidang keliling.

Kriteria perkara yang dapat disidangkan pada sidang keliling. Untuk perkara yang dapat disidangkan pada sidang keliling adalah perkara yang mana kedua belah pihaknya berada di daerah yang akan dilaksanakannya sidang keliling tersebut. Karena daerah-daerah yang akan dilaksanakannya sidang keliling ini dinilai sebagai daerah yang sulit untuk transportasi dan juga merupakan daerah yang jumlah perkaranya banyak. Disini Pengadilan Agama Sampit tidak membedakan apakah pihak-pihak perkara tersebut termasuk kalangan orang yang mampu atau tidak mampu, selama meraka berada di daerah yang akan dilaksanakannya sidang keliling maka perkaranya dapat disidangkan melalui sidang keliling yang diadakan oleh Pengadilan Agama Sampit. Perlakuan seperti ini sesuai dengan asas-asas dalam Peradilan Agama, yakni asas equality ${ }^{34}$ dan asas legalitas ${ }^{35}$ atau asas “persamaan hak dan kedudukan dimuka hukum”. Asas ini diatur dalam pasal 4 ayat (1) dan (2) Undang Undang Nomor 48 Tahun 2009 Tentang Kekuasaan Kehakiman, yang berbunyi : Pengadilan mengadili menurut hukum dengan tidak membeda bedakan orang. Pengadilan membantu pencari keadilan dan berusaha mengatasi segala hambatan dan rintangan untuk dapat tercapainya peradilan yang sederhana, cepat, dan biaya ringan. ${ }^{36}$

Hemat penulis, asas ini sangat tepat diterapkan pada sidang keliling Pengadilan Agama Sampit karena daerah yang akan di jangkau cukup jauh dan medan yang diadakannya sidang keliling tidak hanya melalui jalur darat

\footnotetext{
${ }^{34}$ Setiap orang yang berperkara di muka Pengadilan adalah sama kedudukannya dalam arti sama hak dan kedudukan dihadapan hukum. Lihat Ahmad Mujahidin, Pembaharuan Hukum Acara Perdata Peradilan Agama dan Mahkamah Syar'iyyah di Indonesia, Jakarta: IKAHI, 2008, hal. 19.

${ }^{35}$ Dapat diartikan sebagai hak perlindungan hukum dan sekaligus hak persamaan hukum. Lihat Ahmad Mujahidin, Pembaharuan Hukum Acara Perdata Peradilan Agama dan Mahkamah Syar'iyyah di Indonesia, Jakarta: IKAHI, 2008, hal. 10.

${ }^{36}$ Undang-undang Republik Indonesia Nomor 48 Tahun 2009 Pasal 4 Ayat 1 dan 2.
} 
akan tetapi juga ada melewati jalur perairan. Tujuan dari sidang keliling ini untuk memperingan biaya transportasi bagi para pencari keadilan.

Mengenai lokasi sidang keliling telah disebutkan dalam Pasal 11 ayat (1) Surat Edaran Mahkamah Agung Nomor 10 Tahun 2010: "Sidang keliling dilaksanakan di lokasi yang jauh dari Kantor Pengadilan Agama atau di lokasi yang menyulitkan para pencari keadilan baik dari segi biaya, transportasi maupun proses apabila sidang dilaksanakan di Kantor Pengadilan Agama" 37 Pada ayat tersebut menggunakan kata "jauh" namun tidak diterangkan lebih detail lagi seberapa jauhnya atau harus berjarak berapa kilometer dengan kantor Pengadilan Agama.

Dalam Surat Edaran Mahkamah Agung (SEMA) Nomor 10 Tahun 2010 pada Pasal 15 ayat 2 diterangkan bahwa "sidang keliling dapat melayani perkara biasa dan perkara prodeo". ${ }^{38}$ Penulis dapat mengambil kesimpulan bahwa pada hal ini ada dua point untuk bantuan hukum, karena sidang keliling sendiri merupakan bentuk bantuan hukum yang dibiayai oleh pemerintah (menggunakan biaya anggaran DIPA), akan tetapi dalam sidang keliling ternyata juga ada prodeo (bantuan berperkara secara cuma-cuma). Kedua bentuk bantuan hukum ini dapat berjalan seiringan, padahal keduanya merupakan bentuk bantuan hukum yang berbeda.

Mengenai tata ruang sidang keliling yang dilaksanakan di Kantor Urusan Agama yang ada di tempat terjadinya sidang keliling telah sesuai dengan dekorum ruang persidangan pada persidangan reguler di gedung Pengadilan Agama Pengadilan. Sesuai dengan Pasal 11 ayat (3) lampiran B SEMA No. 10 Tahun 2010, "Ruang sidang keliling diusahakan memenuhi dekorum ruang persidangan demi menjaga martabat Pengadilan". ${ }^{39}$ Majelis Hakim menggunakan pakaian dan atribut yang telah sesuai, meja dan tempat duduk Majelis Hakim terletak di depan berhadapan dengan para pihak. Ketua Majelis Hakim berada ditengah-tengah, sebelah kiri dan kanannya anggota

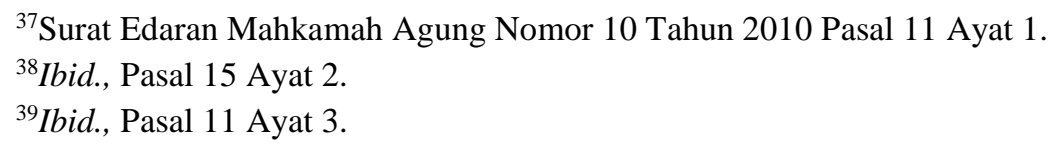


majelis hakim, paling kiri adalah panitera sidang dan Hakim Mediator berada di ruangan tersendiri. Hal ini telah sesuai dengan ketentuan Surat Edaran Mahkamah Agung (SEMA) Nomor 10 Tahun 2010 Tentang Pedoman Bantuan Hukum, Lampiran B Pasal 12 ayat 1 Sidang keliling dapat dilaksanakan oleh sekurang-kurangnya satu majelis hakim dan ayat 2 Sidang keliling wajib dikuti oleh Hakim Mediator dan Pejabat serta staff Pengadilan Agama lainnya sesuai kebutuhan. Berikut tabel data yang menjabarkan kasus sidang keliling yang telah dilaksanakan di Kabupaten Seruyan Kecamatan Seruyan Hilir, Kabupaten Katingan di Kecamatan Katingan Hilir dan di Kecamatan Katingan Tengah pada Tahun 2015.

Tabel 2

Laporan pelaksanaan Sidang Keliling dan Perkara yang disidangkan di Pengadilan Agama pada Tahun 2015

\begin{tabular}{clccc}
\hline No. & Nama Perkara & $\begin{array}{c}\text { Kecamatan } \\
\text { Seruyan Hilir }\end{array}$ & $\begin{array}{c}\text { Kecamatan } \\
\text { Katingan Hilir }\end{array}$ & $\begin{array}{c}\text { Kecamatan } \\
\text { Katingan } \\
\text { Tengah }\end{array}$ \\
\hline 1. & Cerai Gugat & 13 & 9 & 9 \\
\hline 2. & Cerai Talak & 9 & 2 & 2 \\
\hline 3. & Itsbat Nikah & 7 & 5 & - \\
\hline
\end{tabular}

Sumber: Hasil Wawancara dengan Kepala KUA Kecamatan Seruyan Hilir, Kepala KUA Kecamatan Katingan Hilir dan Kepala KUA Kecamatan Katingan Tengah pada Tahun 2015.

\section{E. Kesimpulan}

Bahwa yang melatar belakangi adanya ide pelaksanaan sidang keliling di Pengadilan Agama Sampit ini karena jarak tempuh yang lumayan jauh, letak geografis atau medan tempuh yang tidak hanya melalui jalur darat akan tetapi juga ada yang melalui jalur perairan dan juga dengan dilaksanakannya sidang keliling ini agar memudahkan para pencari keadilan yang berada jauh dari Pengadilan Agama Sampit mendapatkan keadilan dalam bidang hukum. Pedoman atau dasar hukum yang memperbolehkan sidang keliling di Pengadilan Agama Sampit yaitu SEMA No. 10 Tahun 2010 Tentang 
Pedoman Pemberian Bantuan Hukum, serta surat perijinan dari Pengadilan Tinggi Agama Palangka Raya dan Pemerintahan Kabupaten Kotawaringin Timur. Efektivitas pelaksanaannya sidang keliling yang dilaksanakan Pengadilan Agama Sampit berjalan dengan baik dan sangat efektif untuk masyarakat. Hukum acara yang digunakan juga hukum acara yang berlaku pada persidangan biasa (litigasi reguler), yang berbeda hanya pelaksanaannya yang dilakukan di luar gedung Pengadilan Agama Sampit, yakni di Kantor Urusan Agama (KUA) setempat.

\section{DAFTAR PUSTAKA}

Ahmad Noeh, Zaini dan Abdul Basit Adnan, Sejarah Singkat Pengadilan Agama Islam di Indonesia, Surabaya: PT Bina Ilmu, 1980.

Departemen Agama Republik Indonesia, Al-Qur'an dan Terjemahan (QS AlMaidah : 42, Depok: Mushaf Ar-Rusydi, 2008.

Fariha, EFEKTIVITAS PENYELESAIAN PERKARA PERCERAIAN MELALUI SISTEM SIDANG KELILING DI PENGADILAN AGAMA KABUPATEN MALANG JAWA TIMUR, Http://lib.uinmalang.ac.id/?mod=th_detail\&id=10780008. Diunduh pada tanggal 28 April 2015, pukul 15:49 WIB. (dalam bentuk PDF).

Halim, Abdul, Peradilan Agama dalam Politik Hukum di Indonesia, Jakarta: Raja Grafindo Persada, 2000.

Indah Umaroh, ANALISIS SIDANG KELILING PERKARA CERAI GUGAT DI WILAYAH HUKUM PENGADILAN AGAMA MOJOKERTO MENURUT SURAT EDARAN MAHKAMAH AGUNG (SEMA) NOMOR 10 TAHUN 2010, Http://digilib.sunanampel.ac.id/gdl.php?mod=browse \&op=read\&id=jiptiai--indahumaro9504. Diunduh pada tanggal 25 April 2015, pukul 20:53 WIB. (dalam bentuk PDF).

Lubis, Sulaikhan, Hukum Acara Perdata Peradilan Agama di Indonesia, Jakarta: Prenada Media, 2005.

Mujahidin, Ahmad, Pembaharuan Hukum Acara Perdata Peradilan Agama dan Mahkamah Syar'iyyah di Indonesia, Jakarta: IKAHI, 2008.

R. Soeroso, Praktik Hukum Acara Perdata: Tata Cara dan Proses Persidangan, Jakarta: Sinar Grafika, Cet. V, 2003.

Rasyid, Chatib, dan Syaifuddin, Hukum Acara Perdata dalam Teori dan Praktik 
pada Peradilan Agama, Yogyakarta: UII Perss, 2009.

Sejarah Terbentuk dan Perkembangan Pengadilan Agama Sampit. Lihat Http://pasampit.go.id/sejarah-peradilan, diakses pada tanggal 23 Desember 2015 pukul 09.28 WIB.

Surat Edaran Mahkamah Agung Nomor 10 Tahun 2010 Tentang Pedoman Pemberian bantuan hukum pasal 1 ayat (8) ditentukan sidang keliling, Http://bawas.mahkamahagung.go.id /bawasdoc/doc/sema.no_10_tahun_2010.pdf. Diunduh pada tanggal 7 Mei 2015 pukul 16:00 WIB.

Soekanto, Soerjono, Pengantar Penelitian Hukum, Jakarta: Universitas Indonesia (UI-Press), 1986.

Tahapan-tahapan persidangan dalam persidangan keliling, Http://www.pajakartautara.go.id/website/edukasi-masyarakat/proses-tahapanpersidangan.html. Diunduh pada tanggal 7 Mei 2015 pukul 16:00 WIB.

Tata letak dan daerah yuridiksi Pengadilan Agama Sampit, Http://www.pasampit.go.id/. Diunduh pada tanggal 13 Mei 2015. pukul 19:21 WIB.

Tim Penyusun, Undang-undang Peradilan Agama, UU RI Nomor 50 tahun 2009 dan Kompilasi Hukum Islam, Yogyakarta: Pena Pustaka, t.th.

Utsman, Sabian, Metodologi Penelitian Hukum Progresif, Yogyakarta: Pustaka Pelajar, 2014.

Undang-undang Republik Indonesia Nomor 48 Tahun 2009 Pasal 4 Ayat 1 dan 2 Tentang Kekuasaan Kehakiman.

Wilayah Hukum pengadilan Agama Sampit. Lihat Http://pa-sampit.go.id/wilayahyuridis, diakses pada tanggal 23 Desember 2015 pukul 09.30 WIB. 